\title{
Preliminary design of an Initial Test of Integrated Skills within TRADILEX: an ongoing project on the validity of audiovisual translation tools in teaching English
}

Diseño preliminar de un test inicial de destrezas integradas dentro del proyecto TRADILEX: la validez de las herramientas de traducción audiovisual en la enseñanza del inglés

Disseny preliminar d'un test inicial d'habilitats integrades dins de TRADILEX: un projecte educatiu en curs sobre la validesa de les eines de traducció audiovisuals en I'ensenyament de l'anglès com a llengua estrangera

\section{Pilar Couto-Cantero ${ }^{1, * \odot}$, Mariona Sabaté-Carrové ${ }^{2}$, María Carmen Gómez Pérez ${ }^{30}$}

\author{
1 | Didácticas Específicas y Métodos de Investigación y Diagnóstico en Educación, Universidade A Coruña, A \\ Coruña, Spain \\ 2 | Departament d'Anglès i Lingüística, Universitat de Lleida, Lleida, Spain \\ 3 | Dpto. de Estudios Románicos, Franceses, Italianos y Traducción, Universidad Complutense de Madrid, \\ Madrid, España \\ *Corresponding author: pilar.couto@udc.es (Pilar Couto-Cantero)
}

Sabaté-Carrové, M. \&

Gómez Pérez, M. C. (2021).

Preliminary design of an Initial Test of Integrated Skills within TRADILEX: an ongoing project on the validity of audiovisual translation tools in teaching English. Research in Education and Learning Innovation Archives, 27,73-88.

10.7203/realia.27.20634

Copyright: The Authors. Open Access: This article is distributed under the terms of the Creative Commons Attribution-NoDerivatives 4.0 International licence (CC BY-ND 4.0)

Funding: This article is part of the TRADILEX Project (2020-2023) and has been funded by a competitive call by the Spanish Ministry of Science, Innovation and Universities. Reference: PID2019-107362GA-I00

Received: 03/11/2021 | Accepted: 07/09/2021 | Published: 07/15/2021

ABSTRACT: This article shows the preliminary design process for a tailor-made Initial Test of Integrated Skills (ITIS) specially adapted to the needs of TRADILEX, a project (2020-2023) funded by the Spanish Ministry of Science, Innovation and Universities to study the scope and validity of using audiovisual translation (AVT) tools to develop communicative competence in a foreign language. We also design a complete virtual AVT-based teaching platform that will help to promote faster and better EFL learning. In this paper we present one of the project's initial stages, i.e. the ITIS design and the methodological framework for the design process from draft stage to final product. The draft pilot ITIS was tested by specialists, who produced a series of reports and anticipated several potential problems that occurred when the test was carried out. We pay special attention to the changes and improvements made to the draft ITIS as well as its three-stage process and remedial measures. The validity of the ITIS is currently being tested with a pilot group. The ITIS will be complemented with a Final Test of Integrated Skills (FITIS), which is currently underway.

KEYWORDS: foreign language teaching; mediation; instrument design; language assessment; integrated skills

RESUMEN: El objetivo de este artículo es mostrar el proceso de diseño preliminar de un Test Inicial de Destrezas Integradas (TIDI) a medida, especialmente adaptado a las necesidades de TRADILEX, un proyecto (2020-2023) financiado por el Ministerio de Ciencia, Innovación y Universidades, con el objetivo de estudiar el alcance y la validez de las herramientas de traducción audiovisual (TAV) en el desarrollo de la competencia comunicativa de una lengua extranjera. Al mismo tiempo, se pretende diseñar una plataforma de enseñanza virtual completa basada en TAV que dará como resultado 
un aprendizaje de Ia lengua extranjera más rápido y mejor. Este trabajo presenta una de las etapas iniciales del proyecto, con la creación del diseño TIDI y el marco metodológico del proceso de diseño, desde su etapa de borrador hasta su producto final. Una vez elaborado el TIDI piloto, el test fue posteriormente probado por especialistas que redactaron una serie de informes y anticiparon algunos de sus problemas potenciales cuando realmente se llevó a cabo. En este artículo se dedica especial atención a cambios y mejoras en el borrador, su proceso dividido en tres etapas, así como sus medidas correctivas. La validación del TIDI se está probando actualmente con un grupo piloto y se complementará con un test final (TEFIDI) que se encuentra actualmente en curso.

PALABRAS CLAVE: evaluación de lengua; enseñanza de lenguas extranjeras; mediación; diseño instrumental; habilidades integradas

RESUM: L'objectiu d'aquest article és mostrar el procés preliminar de disseny d'un test inicial d'habilitats integrades (TIHI) a mida especialment adaptada a les necessitats de TRADILEX, un projecte (2020-2023) finançat pel Ministeri de Ciència, Innovació i Universitats, amb l'objectiu d'estudiar l'abast i la validesa de les eines de traducció audiovisual en el desenvolupament de la competència comunicativa d'una llengua estrangera. En aquest projecte es dissenya tota una plataforma d'ensenyament virtual basada en AVT que donarà lloc a un aprenentatge EFL més ràpid i millor. Aquest article presenta una de les etapes inicials del projecte: la creació del disseny de TIHI, el seu marc metodològic del procés de disseny, des de la seua fase de redacció fins al seu producte final. En obtenir l'avantprojecte TIHI pilot, posteriorment va ser provat per especialistes que van produir una sèrie d'informes que van posar de manifest $\mathrm{i}$ anticipar alguns dels seus possibles problemes quan es realitzen realment. En aquest article es dedica una atenció especial als canvis i millores de l'esborrany de TIHI, al seu procés de tres fases, així com a les seues mesures correctores. La validació del TIHI s'està provant actualment en un grup pilot i es complementarà amb un test final (TEFIHI) que està en curs.

PARAULES CLAU: ensenyament de llengües estrangeres; disseny instrumental; mediació; habilitats integrades; avaluació de llengua

\section{Practitioner Notes}

\section{What is already known about this topic}

- Language tests often do not combine all the skills: oral and written reception and production.

- Language tests often lack mediation according to the 2018 Companion Volume with new descriptors of the CEFR.

\section{What this paper adds}

- Detailed description of how to carry out a design of an original Initial Test of Integrated Skills (ITIS).

- AVT techniques included in the tailor-made test.

- Mediation included in the design of the integrated skills.

Implications for practice and/or policy

- Designing a tailor-made Initial Test of Integrated Skills can help language teachers better test their students' language skills.

- The design and contents of the ITIS can be transferable and adapted to other assessment and placement tests.

\section{INTRODUCTION AND REVIEW OF THE LITERATURE}

\subsection{TRADILEX project general framework}

The present paper is framed within the TRADILEX Project (2020-2023) funded by the Spanish Ministry of Science, Innovation and Universities, aiming to study the scope and validity of audiovisual translation tools in developing the communicative competence of a foreign language. 
The main goal of TRADILEX is to determine the degree of improvement in the Foreign Language (henceforth FL) learning process after including the pedagogical use of AVT as a teaching and learning tool. To this end, a thorough methodological proposal will be articulated including complete tasks which make use of diverse AVT modes such as subtitling, dubbing or audiodescription. These tasks are designed to enhance communicative competence in an integrated and differentiated manner. This methodology will be piloted with adult students in non-formal educational contexts, especially in language centres of the universities involved. In this regard, the researchers in TRADILEX will elaborate the necessary materials to conduct quasi-experimental research aiming to bring to the fore a representative indication in support of the potential benefits of this methodological approach.

The results will be reflected in the online platform that will disseminate the use of this didactic (teaching and learning) resource. Some of the tasks created within the platform are designed to be undertaken with the help of a subtitle editor and a voice recorder integrated in the web. It is expected that the benefits will then be shared among the population at large, thereby potentially promoting the development of plurilingualism among citizens that increasingly live their lives (and develop their lifelong learning) in a technological and online context. The main FL in the project will be English, given the current importance of this language in our globalised world, coupled with the necessity to make more frequent use of it.

Being TRADILEX a language related project, a common linguistic framework was required. Accordingly, the Common European Framework of Reference for Languages (CEFRL) was adopted as it provides an action-oriented approach aimed at promoting plurilingualism and describing the knowledge and skills that learners need to develop in order to communicate effectively. In a recent revision of that document (Council of Europe, 2018 ) more weight is lent to the role of mediation in FL learning, understood as the language activity of rephrasing a text, orally or in writing, for the purpose of making it comprehensible to speakers of other languages. In mediation, the speaker stands at the centre of the process and collaborates with his/her interlocutors to construct meanings, helping to create the appropriate context for communication and learning to occur. In this sense, the TRADILEX Project includes mediation as a methodological basis through the AVT that students carry out in the corresponding tasks of subtitling, dubbing, audiodescription, etc., which is innovative. Additionally, we consider that the project is also in line with the most current trends in the field of FL teaching and learning and it is also fundamental from a methodological point of view. Students who perform AVT tasks in their learning become audiovisual mediators, by making accessible the video clips with which they interact, either from a plurilingual point of view (cross-linguistic translation) or considering specific needs of sensory accessibility (auditory or visual).

Teaching experience has demonstrated an increase in audiovisual communication. Most of the content produced and received daily comes from audiovisual formats and online environments. The active use of video within an Integrated Communication Technologies context (henceforth ICT), including mediation as a key element of the task, provides a high degree of authenticity to the FL learning process. By using AVT as a didactic resource, learners add subtitles and record their voices, and it will be demonstrated that learners are able to develop the necessary awareness of accessibility. They can also share their final products online with classmates, friends or family. In turn, this promotes the principles of "learner autonomy" and "learning to learn". They also may use the FL in order to facilitate the acquisition of knowledge, competences and skills, which are regarded as powerful and effective communicative tools. This AVT environment helps increase learners' interest in the FL by giving them a clear reason to communicate, including topics of their interest. This AVT environment also creates an easily recognisable, innovative, fully active, and motivating atmosphere. This provides 
greater self-reliance to the learner in their learning process (Incalcaterra, Lertola, \& Talaván, 2018).

While until a few years ago FL classes were complemented with audio documents in order to improve students' communicative skills, nowadays it is difficult to find teachers who do not use audiovisual and technological material to illustrate the contents of each teaching and learning unit (de la Torre, 2011; Motteram, 2013). In this context, it is essential to develop projects that can provide pedagogical models and accurate data to bring ICTs and the educational potential of audiovisual materials and mediation to the largest possible number of users. The field of study dealing with the integration of video in FL teaching and learning has been with us for decades, since the appearance of VHS (Allan, 1985). At first, video was mainly used to work on listening comprehension; however, many other areas are now exploited, such as cultural aspects, linguistic, extralinguistic and paralinguistic information or vocabulary acquisition (Herrero \& Vanderschelden, 2019; Sherman, 2003).

In recent decades, several authors have claimed that the use of video within the classroom has a very positive and motivating effect by offering variety and entertainment while maintaining the instructional character (Bobadilla, 2016; GonzálezVera \& Hornero-Corisco, 2016; Herrero, Sánchez-Requena, \& Escobar, 2018; Thaler, 2014; Vanderplank, 2010; Wagener, 2006; Wang, 2012). Thus, fragments of movies, series, commercials, short films, documentaries, cartoons or music video clips, are increasingly used more habitually and with greater ease for pedagogical purposes in FL learning (Sabaté-Carrove \& Baiget, 2019). The current teaching and learning trend advocate the inclusion of video in class with active participation by students. This participation is also included in the pre-viewing stage, by exploiting the characters or the context, and also in the tasks that take place during the viewing, giving answers to questions about the content, or providing summaries in post-viewing phases (Talavan, 2007; Talaván, 2013). Moreover, the learner can manipulate the video itself thanks to the multimodal resource, and develop free and easy-to-use software for audio editing, include subtitles, or use platforms that integrate these functionalities, as is the case with Clipflair (Sokoli, 2015).

AVT is the professional and academic field in which the linguistic and cultural transfer of an audiovisual text is carried out and studied, that is, a text whose message arises from the combination and interaction between an acoustic and a visual channel (Talaván, Lertola, \& Costal, 2016). Such a transfer can take place through electronic media (e.g. cinema, television, DVD and video games) or non-electronic media (e.g. theatre, opera, etc.). This broad framework of study is in turn divided into different subtypes ranging from traditional modalities (dubbing, subtitling or voiceover) to others less developed at this moment, but of growing interest, such as subtitling for the deaf, audiodescription for the blind and video game localization. This growing interest is in line with the increasing attention devoted to diversity, accessibility and inclusion demanded by $21^{\text {st }}$ century societies. The first two mentioned modalities are the most widespread: while dubbing includes a translation aimed at replacing the voices of the original actors with others that reproduce the script in another language, subtitling involves the inclusion of a written text within the image as a translation (either in FL or in the mother tongue) of the soundtrack of the audiovisual product. Today, AVT is possibly the linguistic-cultural transfer modality that has experienced the greatest boost, given that we are immersed in the global knowledge society and the digital and audiovisual revolution (Chaume, 2018; Díaz-Cintas, 2018). From the technological and software development point of view, the discipline has experienced a dizzying advance in the last decade, especially in terms of subtitling (Roales-Ruiz, 2018). For its part, it should be noted that today, much of the professional practice of this discipline is developed in online environments (Bolaños, 2018). 
The didactic application of AVT to FL learning dates to the 1980s, when several educators and researchers began to analyse the use of subtitles as a support in language labs to improve various skills (Vanderplank, 1988, 2016). AVT, as a didactic support resource and as an active tool, comes in multiple forms. As seen in the literature below, subtitling as a learning support resource has been one of the most researched modalities, showing that there are multiple benefits from various combinations of subtitles: interlingual or standard (FL-mother tongue), intralingual or bimodal (FL-FL). All of them facilitate FL teaching-learning and foster the development of communicative competence in an integrated way (Danan, 2015; Frumuselu, De-Maeyer, Donche, \& Plana, 2015; Talaván, 2013). In the last thirty years, researchers' interest has grown, and this trend has resulted in an extensive number of studies that have demonstrated the benefits of AVT as a support in the development of various FL competences (Caimi, 2006; García-Escribano, 2017; Ghia, 2012; Holobow, Lambert, \& Sayegh, 1984; Perego, Del-Missier, \& Bottiroli, 2015; Vanderplank, 2016).

At the beginning of the 21st century, the active aspect of the didactic application of AVT to the FL teaching-learning environment began to be explored. Most of the modalities of AVT can be applied as a teaching-learning resource in this context and many of them are already put into practice in classrooms and online environments and have been investigated, with an increasing degree of interest, over the last 10 years (Incalcaterra et al., 2018; Sánchez-Requena, 2018). First, didactic AVT was analysed in terms of standard cross-linguistic (FL to mother tongue) subtitling, i.e., learners subtitling teacher-selected videos (Incalcaterra, 2009; Lertola, 2012; Sokoli, 2006; Talaván, 2010; Williams \& Thorne, 2000). Later, other modalities such as dubbing, audiodescription or voiceover, as well as other combinations of subtitling also began to be used in teaching and research in academia (Danan, 2010; Requena, 2016; Talaván \& Lertola, 2016; Talaván et al., 2016; Talaván \& Rodríguez-Arancón, 2014, 2018).

Thus, in the last decade, several studies have shown the benefits of using AVT as an active teaching resource, many of them published by researchers participating in the TRADILEX Project. Finally, it is worth noting other proposals that include either a combination of modalities (Lertola \& Mariotti, 2017; Talaván \& Ávila Cabrera, 2015), proposals for integration into the curriculum (Incalcaterra \& Lertola, 2014), or even their application to Content Language Integrated Learning (CLIL) environments (Couto-Cantero \& Bobadilla, 2018; Fernández-Costales, 2017; FernándezSanjurjo, Fernández-Costales, Blanco, \& M, 2019).

Several Spanish centres and researchers have participated in previous projects, but there is still no consolidated multidisciplinary group (with experts in the field of the didactic application of AVT, as well as specialists in FL didactics, in AVT and in the use of ICT in education), neither in our country nor at the European level, whose main line of work is precisely the pedagogical use of AVT. The implementation of this paper falls within the scope of the TRADILEX Project aims. The design and testing of the ITIS is a preliminary step within the project and the starting point of its ensuing research.

To sum up, this article will describe and analyse the preliminary design of an Initial Test of Integrated Skills (ITIS) within the context of the TRADILEX Project. In the following section, the main hypothesis and objectives of the ITIS design will be presented.

\subsection{Hypothesis and objectives of the ITIS design}

The starting hypothesis of this article is supported by the results and previous contributions of the researchers participating in this proposal, mentioned in previous paragraphs. Many of these contributions are reflected in a recent monograph written by a member of the work team (Lertola, 2019), which exhaustively reviews the literature in the area. The hypothesis consists in demonstrating that the design of a new test of integrated skills will help the assessment quality, as opposed to existing traditional 
assessment tests. To this end, the following objectives will be pursued falling in the intersecting areas of (i) foreign language teaching assessment standards, (ii) ICT and AVT as teaching tools, and (iii) mediation in integrated skills.

As regards the first objective, the ITIS is an essential preliminary step aiming to verify and certify that the students' actual initial level of competence in EFL is in accordance with a B1 level (corresponding to independent users fluent enough to communicate without effort with native speakers) of the CEFRL as our chosen international standard for defining language competence in English. Moreover, this ITIS is in line with a trend in language assessment that evaluates the examinees' abilities by integrating source reading or listening material into their writing and speaking performance in ways that simulate the cognitive, communication, and literacy demands of real-life academic or vocational tasks (Cumming, 2013). This ITIS attempts to offer a diagnostic report of the actual English level of the participants of the project, as well as enhance authentic language-use situations (Gebril, 2018; Plakans, 2021), as opposed to skills tested separately (Kormos, Brunfaut, \& Michel, 2020).

The second objective lies in the fact that our methodology integrates ICT and AVT as didactic resources to improve the teaching and learning FL process. Also, the ITIS theoretical background builds on previous studies (Requena, 2016; Talaván, 2010) that have yielded promising results on the teaching-learning use of AVT in the FL classroom to validate and test the extent of the effectiveness of the proposed methodology. So far, most of the published results present small-scale independent studies and data obtained from short-term interventions. Additionally, unlike previous studies mentioned above whose focus is on technological aspects as software development, the ITIS design focuses more on methodological issues. Namely, these issues are based on the teaching-learning use and review that is intended to be implemented in an open access online platform for the TRADILEX Project.

The last and third objective revolves around mediation in integrated skills. Mediation, as set before, is understood as the language activity of rephrasing a text, orally or in writing, for the purpose of making it comprehensible to speakers of other languages. The audiovisual component brings pedagogical, linguistic, cultural and cognitive advantages to the teaching and learning process and it has a great educational potential specifically for young born-digital learners of a FL. Besides the revision of the Companion Volume (of Europe, 2018) in which the role of mediation in FL learning acquires a leading role, other integrated skills tests were consulted for inspiration, such as the specifications issued by the Trinity College London Examination Board (2020). In accordance with this, mediation standards and integrated skills were taken into account in the design of the ITIS B1. Therefore, instructions, suggestions, questions, and answers were elaborated in the light of mediation elements. It should be noted that this mediation was implemented and integrated in all the language skills of the ITIS. We undertook the task of designing an ITIS that, from the ground up, established a consistent methodological pattern that paved the way for the student to follow.

\section{MATERIALS AND METHODS}

In-depth analysis and description of the materials and methods are very important to accomplish successfully the objectives planned for any scientific research. Therefore, this research has to be empirical and reliable. The quality of this ITIS test design was implemented by means of a contrasted group of international researchers and a structured methodological process described hereinafter. As mentioned above, one of the first instruments to gather data for the TRADILEX Project is the design of an Initial Test of Integrated Skills according to the CEFRL mother tongue level. This ITIS is aimed at measuring the general level of knowledge of the English Language of the sample and the developmental level of the different communicative skills. 


\subsection{Participants}

According to the planning and tasks distributed among all the members of the TRADILEX Project, the authors of this paper oversaw the design of the instrument (ITIS). As part of the previous tasks implemented, a 25-hour course about quantitative and qualitative research methods was completed by all the 20 members of the TRADILEX Project, in order to be better prepared to elaborate the above-mentioned instrument. Moreover, several international members of the Project took part during the process of the design when required to improve, assess or evaluate the instrument within its different phases. Their review reports will be described in the corresponding section of this article.

Other reports piloted by voluntary students from different language centres in Spain are still underway. Their suggestions and comments about the preliminary ITIS are encouraging. The results will be published in further papers as soon as they are available.

\subsection{Design of the ITIS}

As a starting point to design the instrument of this research, the authors counted on various models used previously and published by the researchers of the TRADILEX Project in other innovative proposals and papers related to this area of study (Martínez-Sierra, 2018; Pereira-Varela, 2014; Romero, Torres-Hostench, \& Sokoli, 2011; Sokoli, 2018). Additionally, other integrated skills tests were consulted for inspiration, namely: TEAP, Test of English for Academic Purposes: Associated Examinations Board (Weir, 2014); IELTS, Writing Task 1: Cambridge English, and the specifications issued by the Trinity College London Examination Board, 2020. Nevertheless, it is worth mentioning that the ITIS has been originally and specifically elaborated for the TRADILEX Project, and it is expected that it will be used as a model for the future, as it has been receiving encouraging reports from external evaluators and peer participants. This point will be further developed in Section 2.4.

The ITIS was designed in three phases. First, the structure and sections of the template were discussed and designed in a Word document. After reaching the consensus of dividing the ITIS into 4 sections, the following order was established. To begin with, Oral Reception followed by Oral Production. Then, Written Reception and finally Written Production. Further information about the reason for this order will be delivered in the discussion section.

The topics of the contents of the tasks were selected according to appealing criteria and trying to capture the students' attention and motivation. Some of the topics are the following: "Science is for everyone", " 5 reasons why you should sleep more", "How whales can teach us about us", "Make the Most of your Free Time", "Country Kids" and "TV series". The intention for the titles was to make them as descriptive and unambiguous as possible for the learner. Both the duration of the videos for the reception activities, and the duration of the production activities was commonly agreed among the designers of the instrument. The videos were designed to last between 1'.30" to 2'.00" bearing in mind that participants could listen to them twice. The overriding priority was for the whole ITIS not to exceed 2 hours.

Another aspect taken into account was the length of the writing tasks. The first proposal was for the student to write 200-250 words, but after consideration it was reduced to 100-150 words. In the discussion section, further details will be provided on this matter. Other technical issues were determined and agreed by the authors during the drafting process of the ITIS. The content, skills, and specific features of the template were discussed, and general instructions were presented as can be seen in Figure 1.

The second phase was directed to improve the first draft according to the mother tongue standards and the Project requirements. One of the main aspects dealt with 


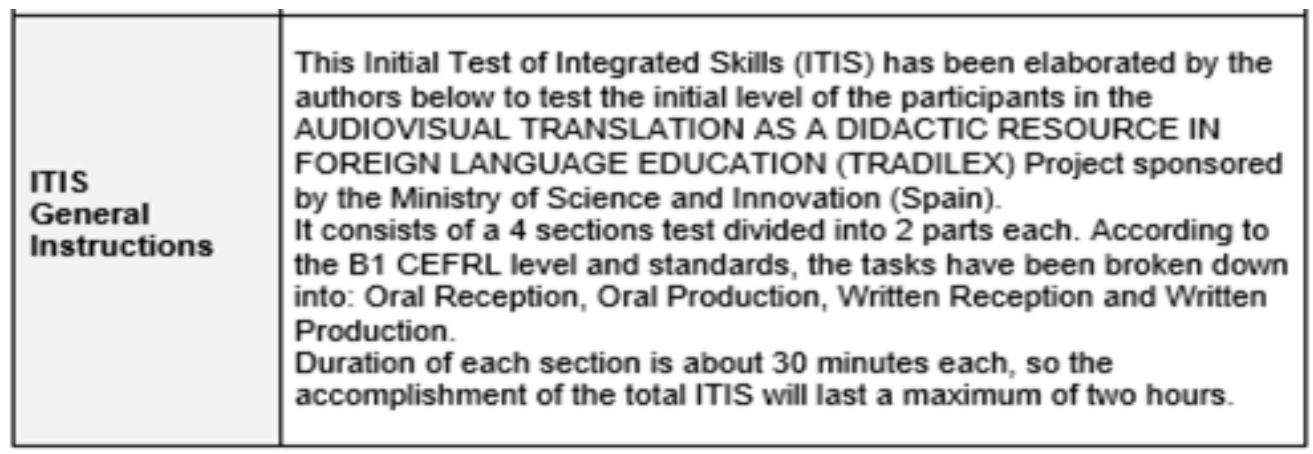

Figure 1. ITIS General Instructions. Source: Own elaboration.

was the number of questions and answers for each section and the type of response to be obtained (multiple choice, true/false answers, choose the correct answer, etc). Finally, it was decided that the proper number of questions for each section would be 5, with 3 possible answers. Additionally, the first draft was converted into a web-based online edition (Google Forms) to make the ITIS more appealing, easy to handle, to make it impossible for users to edit and to make it a reliable instrument (See Figure 2).

Phase 1. ITIS Word template

\begin{tabular}{|l|l|l|}
\hline \multicolumn{2}{|l|}{$\begin{array}{l}\text { Initial Test of Integrated Skills. InS } \\
\text { (Test Inicial de Destrezas Integradas. nDI) }\end{array}$} \\
\hline $\begin{array}{l}\text { Modality } \\
\text { Context }\end{array}$ & Online \\
\hline $\begin{array}{l}\text { CEFRL } \\
\text { Level }\end{array}$ & B 1 \\
\hline $\begin{array}{l}\text { Total } \\
\text { Duration }\end{array}$ & 2 hours \\
\hline Contents & $\begin{array}{l}4 \text { sections } \\
\text { (15 min. } \\
\text { each) }\end{array}$ & $\begin{array}{l}\text { Oral Reception } \\
\text { Written Reception } \\
\text { Written Production }\end{array}$ \\
\hline $\begin{array}{l}\text { Ins } \\
\text { General } \\
\text { Instructions }\end{array}$ & $\begin{array}{l}\text { This Initial Test of Integrated Skils } \\
\text { (ITIS) has been elaborated by the } \\
\text { authors below to test the initial } \\
\text { level of the participants in the } \\
\text { TRADILEX Project sponsored by } \\
\text { the Ministry of Science and } \\
\text { Innovation (Spain). }\end{array}$ \\
\hline
\end{tabular}

Phase 2. ITIS Google forms

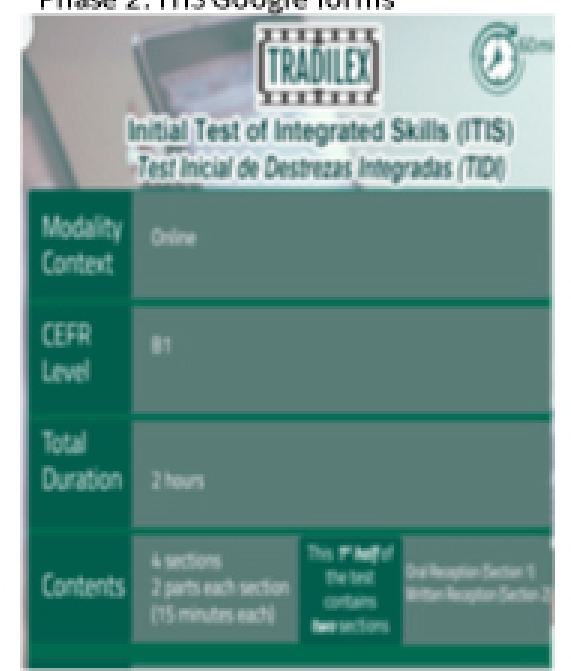

Figure 2. ITIS screenshots. Phase 1 and Phase 2. Source: Own elaboration.

Finally, in the third and final phase, all suggestions and improvements recommended by the reviewers were considered to refine the ITIS prior to its final stage. For example, all reviewers strongly suggested the division of the instrument into 2 parts of 1 hour each. Figure 3 shows a sample screenshot of the final ITIS B1. The complete ITIS instrument can be found in the Appendix A.

\subsection{Procedure}

Among the TRADILEX Project members, the three authors of this paper were assigned the elaboration of the ITIS B1. Since they are established in different universities from the West, East and Centre of Spain and, due to the lockdown caused by the pandemic, it was agreed that the meeting place would be an online platform (Microsoft TEAMS). The meeting schedule would be from late January to March 2021 on a weekly basis. A total of 16 hours were devoted to justifying, creating, and deciding how to proceed according to the pre-stablished parameters of the Project. 


\section{Section 1 | Oral Reception | Part 2 (15 minutes)}

Link: https://anglosaxonsecrets.es/enrol/index.php?id=10

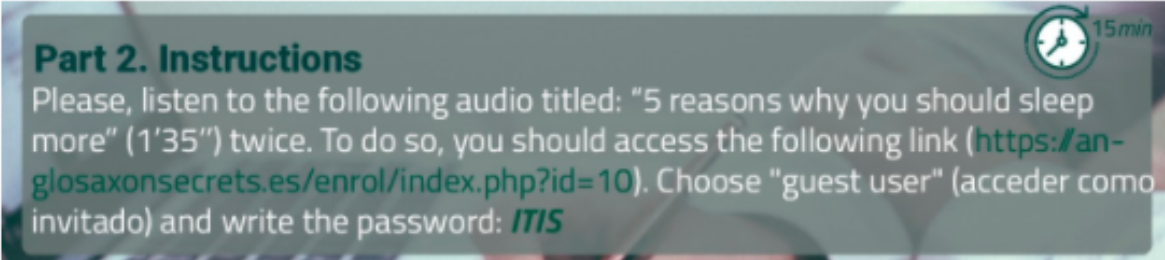

This is what you will find in the website once you have written the password. Click on the file shown in the image.

Initial Test of Integrated Skills. ITIS Section 2. Oral Reception

En esta seccion se encuentra el fichero para la sequnda sección del test de "Oral Reception": Por favor, haz dic cuando estés preparado/a para realzar la escucha y responde a las cuestiones que se plantean en Google forms.

III Initial Test of Integrated Skills. ITIS Section 2. Oral Reception

1. Why sleep is so important according to the speaker? *

Because it helps your memory and learning ability run faster.

Because it improves your memory and it stimulates your learning ability.

Because it refreshes your memory and learning ability.

Figure 3. ITIS screenshot. Phase 3. Source: Own elaboration

After an in-depth bibliographic review of existing literature and reference sources, each member of the group made a proposal in line with the main elements of the theoretical foundations presented. The idea of elaborating an innovative ITIS that differed from existing traditional ones, like those issued by the Cambridge-OxfordTrinity College Examination Board, was of paramount importance. The intention was to create a tool especially adapted to the needs of the project, the students and the scope outlined. Added to this, the ITIS had to be reliable, appealing, and appropriate for a CEFRL B1 level student. Above all, it was important that the design included integrated skills (productive and receptive, oral and written) with a special emphasis on mediation. For example, the design of the questions in the reception section included mediation as students had to rephrase a text for the purpose of making it comprehensible to other speakers. Finally, rigorous and adequate use of the English language in the final design of the ITIS was mandatory. 
The three authors of this paper had regular meetings to solve and improve the design of the ITIS B1 and worked as a team throughout the process. However, each author oversaw a particular aspect of the design of the instrument, so that the researcher on AVT paid special attention to the selection and final election of the listenings, readings and audiovisual materials to be presented as part of the instrument. The second researcher undertook the task of elaborating the questions, activities and answers to be given out of the previously selected texts. Finally, the third researcher designed the basic structure of the test and tried to give coherence and integrate the different sections of the ITIS B1. A final consensus was then achieved by all the researchers at the end of the design process.

Regarding general questions and topics to deal with, both cultural and social issues were discussed, and these authors were very much concerned about selecting interesting topics to engage the participants. As already mentioned, the ITIS B1 was made out of a total of 4 sections with 2 parts for each section specifically designed to measure a B1 level of English Language Learning according to the CEFRL (2018). The maximum duration of the ITIS was 2 hours. The format of the questions as well as the answers to the questions combined multiple input and output tools, e.g., voice recording (by means of https://vocaroo.com), multiple choice questions, paragraph typing (100-150 words) and video playing (1'30"-2' talk), as can be seen in the Appendix A.

Finally, it is also important to underline that all the materials used for the design of this ITIS were only used for educational purposes and the videos and texts used were adapted or trimmed from downloadable webpages.

\subsection{Review of the instrument}

Any instrument designed for a scientific study of this kind has to be validated by an expert panel and tested by a substantial number of participants in a preceding piloting phase. In the process of validation of this ITIS, which is underway, preliminary reports are being obtained from the expert panel, random report reviewers, and one technical collaborator. Timing of the test, contents, aesthetic appearance and any relevant detail to improve the design of the web-based instrument are being analysed by these parties in order to obtain the best results. The piloting stage is being implemented at the moment, and positive feedback and good results have so far arisen according to the reports from the advisors. (See Figures 4 and 5 below).

\section{|lnforme sobre prueba de evaluación inicial TIDI} A modo de resumen me parece una prueba perfectamente diseñada para el nivel B1. Creo que todas las actividades son pertinentes y evalúan correctamente las competencias del MCER para dicho nivel. Adjunto algunas observaciones y sugerencias sobre la digitalización de las actividades de comprensión oral.

Figure 4. ITIS B1 Report. Source: Reviewer 1

Evaluación del Test Inicial de Destrezas Integradas (TIDI)

No se han observado grandes problemas durante el desarrollo del Test Inicial de Destrezas Integradas (TIDI). Los puntos que se mencionan a continuación son únicamente algunas propuestas de mejora o comprobación.

Figure 5. ITIS B1 Report. Source: Reviewer 2 
There are more corrections and suggestions on both reports, but most of them revolved around benefits for the sake of user-friendliness, optimisation of the web-based ITIS and other technical improvements for the interface. Since this stage of the project is still preliminary, further reports are due, and there are likely to be more changes.

\section{DISCUSSION}

The ITIS B1 was designed for a specific purpose, and at this preliminary stage, the originality of our instrument was based on creating an assessment tool for a B1 level of competence with the introduction of AVT as a parameter to assess the students' English language level. Introducing the mediation element in the ITIS may involve maximising teaching and learning benefits. Although there are previous models of initial tests (Martínez-Sierra, 2018; Pereira-Varela, 2014; Romero et al., 2011; Sokoli, 2018), this article provides a series of hands-on and functional guidelines for designing a tailor-made initial test of integrated skills. Once the online platform with the tasks and activities designed is launched, the ITIS B1 will be available to any user (either teachers or students) who may be interested in benefiting from this new and holistic type of assessment.

According to internal and external reviewers, the instrument had to be divided into 2 different pieces of assessment. This is why one important issue for the authors was to consider whether the order of delivery of the tasks should be guided in one direction or another. The first possibility was to begin with oral reception and oral production in one part, followed by the second piece of assessment consisting of written reception and written production. The second possibility was to begin with oral reception and written reception and continue with oral production and written production. After some discussion among the ITIS designers, and in response to suggestions by project members and reviewers, it was finally decided that the latter would be implemented.

In this discussion, pros and cons of these possibilities were analysed. The former was better for students as it allowed them enough time to complete all the tasks, as there was a balance between receptive and productive skills. While the latter was not detrimental to students, it was better for researchers, as it facilitated grouping skills together and facilitated data analysis. At this point, another discussion that deserves special attention is the length of the ITIS. The earlier drafts included different lengths for each task ranging between 8 and 10 items. After checking the reviewers' reports, decision was reached to give a uniform number of items to each task and agreed on a total of 5. It was also agreed that multiple-choice options should not exceed 3.

As regards the length of the writing tasks, the first proposal was for the students to write between 200-250 words. However, after suggestions from the revisors and checking other existing tests, agreement was reached to shorten them to 100-150 words. After discussion, it was considered that production activities require more effort than reception activities, motivating this reduction.

The design of the ITIS instrument is a much-needed didactic tool, as well as a powerful initial tool to use AVT to improve the teaching and learning process of foreign languages. Besides its usefulness within the TRADILEX Project, the complete final product of this ITIS can be used by teachers and colleagues and shared with others via the web. There is currently a limited amount of material prepared and ready to use as regards placement tests. Although some teaching institutions and examination boards offer useful guidelines on how certain CEFRL-based exams are created, developed and assessed, there is, to our knowledge, no test that integrates all the skills and is available, and can be completed online. In our search for similar exams, all the instructions of mediation were poor or non-existent. This research offers teachers the possibility to either use the ITIS (once the whole project is available online), or design their own tailor-made test based on our ITIS as a reliable placement test. At the moment, the 
test cannot be used for official purposes, but rather as a pilot diagnostic tool to assist language learners and teachers. In the near future, it is expected that the test will be fully available, as soon as official registration of the instrument is approved.

\section{LIMITATIONS AND CONCLUSIONS}

Despite the encouraging findings in the final result of the design process of the ITIS, these authors are aware of the limitations of the present paper. To begin with, the testing process of the ITIS has not been finalized yet, as the pilot testing is still underway. However, satisfactory provisional results are already available. We look forward to issuing further results in the near future. Another limitation of this ITIS derives from lack of in-depth feedback from the students, and the difficulty of having a contrastive analysis of their feedback, i.e. current reaction, impressions, feelings and shortcomings to this test against previous "placement" tests. However, we envisage to check on the above and deliver such information in a forthcoming article.

As soon as the ITIS has been tested with a group of pilot students, their feedback will help us reinforce the validity of the test. Possibly, some aspects will have to be adjusted, while others may meet the requirements. The design of the ITIS B1 will be completed with the design of a Final test (FITIS B1). In fact, the design of the FITIS will, in all probability, be faster and more effective, because of the experience gathered with the design of the ITIS. By the same token, these authors will design the ITIS and FITIS B2 to evaluate B2-level students, as one part of the TRADILEX Project is also intended for this CEFRL level. The authors suggest that the work analysed here should be viewed as a small part of a larger wider-ranging project. The follow-up to this article will be found in forthcoming studies and research related to the TRADILEX Project.

Despite the above-mentioned limitations of this study, the authors of this paper have drawn a series of positive conclusions. To start with, thanks to this ITIS an innovative, motivating and appealing instrument for FL assessment has been elaborated. The materials used for reading, listening, speaking and writing have been selected on the basis of their authenticity. The topics dealt with are updated in order to promote significant learning and elicit curiosity from users. Moreover, in choosing the topics for assessment, intercultural, cognitive and social issues that could be of interest to $21^{\text {st }}$ century users were considered, as suggested by the CEFRL.

A second conclusion worth highlighting is that the ITIS has gone one step further to avoid stereotypical FL tests. In this respect, the elaboration of this ITIS includes new ways of assessing languages never explored before. The approach to create this ITIS is also integrative and holistic so that all the tasks are interconnected, giving the instrument a global and thorough perspective. By means of the ITIS, where AVT tools (e.g. the use of Vocaroo) were used to complete the test, we purposefully intended to prepare students to become accustomed to manipulate AVT apps and tools. And also being aware that this early exposure to using AVT techniques would be necessary to later develop the Lesson Plans of the TRADILEX Project effectively.

The authors of this article may conclude that the initial hypothesis and objectives planned in this article: i) designing an ITIS that could become a foreign language teaching assessment standard; ii) promoting ICT and AVT as teaching tools; and iii) using mediation in integrated skills have been accomplished.

\section{A. APPENDIX}

\section{ITIS B1 RECEPTION SKILLS}

This is a screenshot of the ITIS B1 RECEPTION SKILLS. 


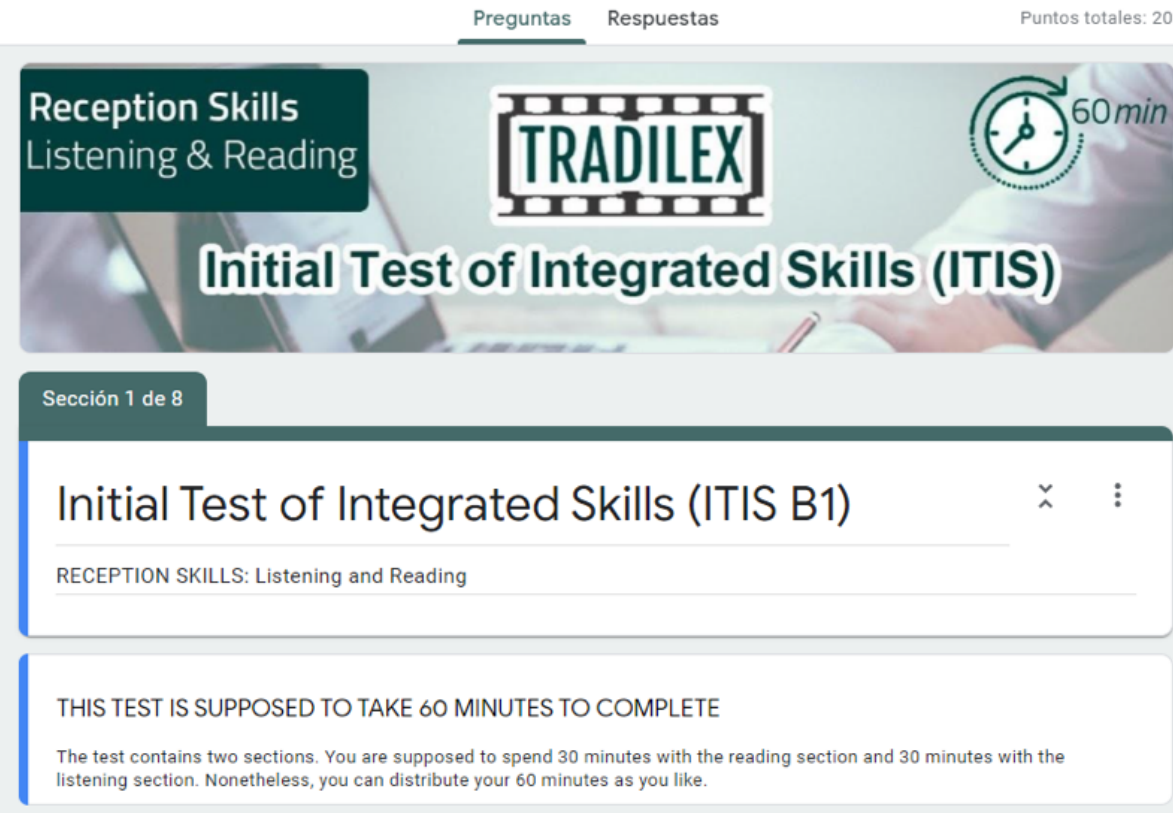

Full document is available online in the following links:

Listening \& Reading:

https://forms.gle/EkVEBXPstm1fVdYD7

Speaking \& Writing:

https://forms.gle/u2rDz8wRFLCSYBt2A

\section{REFERENCES}

Allan, M. (1985). Teaching English with Video. Essex: Longman Group Limited.

Bobadilla, M. (2016). Las TIC en el aula de Lengua extranjera a edades tempranas:

Los cuentos audiovisuales como recurso. In J. Jacinto-Esola, M. Raposo-Rivas,

A. P. Florêncio-Aires, \& M.-E. Martínez-Figueira (Eds.), Experiencias de Investigación e intervención educativa con las TIC (pp. 275-285). Almería: Procompal Ediciones.

Bolaños, A. (2018). The Pedagogical Potential of Cloud-Based Platforms: A Study on the Didactics of Subtitling in Online Translator Training Environments. In J. D. Sanderson \& C. Botella (Eds.), Focusing on Audiovisual Translation Research (pp. 63-94). Valencia: Universitat de València.

Caimi, A. (2006). Audiovisual Translation and Language Learning: The Promotion of Intralingual Subtitles. FoSTrans. The fournal of Specialised Translation(6), 84-98. Retrieved from https://www.jostrans.org/issue06/art_caimi.php

Chaume, F. (2018). An overview of audiovisual translation: Four methodological turns in a mature discipline. Journal of Audiovisual Translation, 1(1), 40-63. https://doi.org/ 10.47476/jat.v1i1.43

Couto-Cantero, P., \& Bobadilla, M. (2018). Ten Fundamentals for CLIL Teachers. E-TEALS an efournal of Teacher Education and Applied Language Studies, 9, 108-131.

Cumming, A. (2013). Assessing integrated skills. In A. Kunnan (Ed.), The companion to language assessment (Vol. 1, pp. 216-229). Retrieved from https://doi.org/10.1002/ 9781118411360.wbcla131

Danan, M. (2010). Dubbing projects for the language learner: a framework for integrating audiovisual translation into task-based instruction. Computer Assisted Language 
Learning, 23(5), 441-456. https://dx.doi.org/10.1080/09588221.2010.522528

Danan, M. (2015). Subtitling as a language learning tool:past findings, current applications, and future paths. In Y. Gambier, A. Caimi, \& C. Mariotti (Eds.), Subtitles and Language Learning. Principles, strategies and practical experiences (pp. 41-61). Berna: Peter Lang.

de la Torre, M. J. (2011). Improving spoken competence by means of multimodal environments in a distance context. Revista de Lingüística y Lenguas Aplicadas, 6, 229241. https://doi.org/10.4995/rlyla.2011.905

Díaz-Cintas, J. (2018). 'Subtitling's a carnival': New practices in cyberspace. The fournal of Specialised Translation, 30, 127-149. Retrieved from https://www.jostrans.org/issue30/ art_diaz-cintas.pdf

Fernández-Costales, A. (2017). Subtitling in CLIL: Promoting Bilingual Methodologies through Audiovisual Translation. Bilingual Education: Trends and Key Concepts (pp. 185-196). Madrid: Ministerio de Educación, Cultura y Deporte.

Fernández-Sanjurjo, J., Fernández-Costales, A., Blanco, A., \& M, J. (2019). Analysing students' content-learning in science in CLIL vs. non-CLIL programmes: empirical evidence from Spain. International fournal of Bilingual Education and Bilingualism, 22(6), 661674.

Frumuselu, A. D., De-Maeyer, S., Donche, V., \& Plana, M.-M. G. C. (2015). Television series inside the EFL classroom: Bridging the gap between teaching and learning informal language through subtitles. Linguistics and Education, 107-117. https://doi.org/10.1016/ j.linged.2015.10.001

García-Escribano, A. B. (2017). The effects of fansubs on EFL education for Translation and Interpreting students: an empirical approach. FoSTrans. The fournal of Specialised Translation, 28, 122-163. Retrieved from https://discovery.ucl.ac.uk/id/eprint/1567974/ 1/art_bolanos.pdf

Gebril, A. (2018). Integrated-Skills Assessment. In S. A. ur Hassan et al. (Eds.), The TESOL Encyclopedia of English Language Teaching (pp. 1-7). Retrieved from https://doi.org/ 10.1002/9781118784235.eelt0544

Ghia, E. (2012). Subtitling Matters: New Perspectives on Subtitling and Foreign Language Learning. Oxford: Peter Lang.

González-Vera, P., \& Hornero-Corisco, A. (2016). Audiovisual Materials: A way to reinforce listening skills in primary school teacher education. Language Value, 8, 1-25. https:// doi.org/10.6035/LanguageV.2016.8.2

Herrero, C., Sánchez-Requena, A., \& Escobar, M. (2018). Una propuesta triple. Análisis fílmico, traducción audiovisual y enseñanza de lenguas extranjeras. InTRAlinea: Online Translation fournal(19). Retrieved from http://www.intralinea.org/specials/article/ 2245

Herrero, C., \& Vanderschelden, I. (Eds.). (2019). Using Film and Media in the Language Classroom: Reflections on Research-led Teaching. Bristol: Multilingual Matters. https:// doi.org/10.21832/HERRER4481

Holobow, N. E., Lambert, W. E., \& Sayegh, L. (1984). Pairing Script and Dialogue: Combinations that Show Promise for Second or Foreign Language Learning. Language Learning, 34(4), 59-74. https://dx.doi.org/10.1111/j.1467-1770.1984.tb00352.x

Incalcaterra, L. (2009). Inter-semiotic translation in foreign language acquisition: The case of subtitles. In A. Witte, T. Harden, \& A. R. de Oliveira (Eds.), Translation in second language learning and teaching (pp. 227-244). Bern: Peter Lang.

Incalcaterra, L., \& Lertola, J. (2014). Audiovisual translation in second language acquisition. Integrating subtitling in the foreign-language curriculum. The Interpreter and Translator Trainer, 8(1), 70-83. https://dx.doi.org/10.1080/1750399x.2014.908558

Incalcaterra, L., Lertola, J., \& Talaván, N. (2018). Editorial. Translation and Translanguaging in Multilingual Contexts, 4(1), 1-9. https://doi.org/10.1075/ttmc.00001.edi

Kormos, J., Brunfaut, T., \& Michel, M. (2020). Motivational Factors in Computer-administered Integrated Skills Tasks: A Study of Young Learners. Language Assessment Quarterly, 
17(1), 43-59. https://dx.doi.org/10.1080/15434303.2019.1664551

Lertola, J. (2012). The effect of the subtitling task on vocabulary learning. In A. Pym \& D. Orrego-Carmona (Eds.), Translation research projects 4 (pp. 61-70). Tarragona: Intercultural Research Group- URV. Retrieved from http://www.intercultural.urv.cat/ media/upload/domain_317/arxius/TP4/isgbook4_web.pdf

Lertola, J. (Ed.). (2019). Audiovisual translation in the foreign language classroom: applications in the teaching of English and other foreign languages. Voillans (France): Research Publishing. Retrieved from https://files.eric.ed.gov/fulltext/ED593736.pdf

Lertola, J., \& Mariotti, C. (2017). Reverse Dubbing and Subtitling: Raising Pragmatic Awareness in Italian ESL Learners. FoSTrans. The fournal of Specialised Translation, 28, 103-121. Retrieved from https://www.jostrans.org/issue28/art_lertola.pdf

Martínez-Sierra, J. J. (2018). PluriTAV: Audiovisual Translation as a Tool for the Development of Multilingual Competencies in the Classroom. In T. Read, S. Montaner, \& B. Sedano (Eds.), Technological Innovation for Specialized Linguistic Domains. Languages for Digital Lives and Cultures. Proceedings of TISLID' (Vol. 18, pp. 85-95).

Motteram, G. (2013). Innovations in learning technologies for English language teaching. London: British Council. Retrieved from http://www.teachingenglish.org.uk/sites/ teacheng/files/C607\%20Information\%20and\%20Communication_WEB\%20ONLY_FINAL .pdf

of Europe, C. (2018). Common European Framework of Reference for Languages: Learning, Teaching, Assessment: Companion Volume with New Descriptors. Brussels. Retrieved from https://rm.coe.int/common-european-framework-of-reference-for-languages -learning-teaching/16809ea0d4

Perego, E., Del-Missier, F., \& Bottiroli, S. (2015). Dubbing versus subtitling in young and older adults: cognitive and evaluative aspects. Perspectives, 23(1), 1-21. https://doi.org/ 10.1080/0907676X.2014.912343

Pereira-Varela, J. (2014). Diseño, desarrollo y validación de soluciones tecnológicas para la práctica de la expresión oral de segundas lenguas mediante un entorno colaborativo e interactivo de código abierto: Babelium project. Unpublished doctoral thesis (Unpublished doctoral dissertation). UPV-EHU.

Plakans, L. (2021). Assessment of integrated skills. In C. A. Chapelle (Ed.), The encyclopedia of applied linguistics. Retrieved from https://doi.org/10.1002/9781405198431.wbeal0046 .pub2

Requena, A. S. (2016). Audiovisual Translation in Teaching Foreign Languages: Contributions of Dubbing to Develop Fluency and Pronunciation in Spontaneous Conversations. Porta Linguarum Revista Interuniversitaria de Didáctica de las Lenguas Extranjeras, 26, 9-21. https://dx.doi.org/10.30827/digibug. 53920

Roales-Ruiz, A. (2018). Didáctica de la subtitulación: una propuesta tecnológica. Granada: Editorial Comares.

Romero, L., Torres-Hostench, O., \& Sokoli, S. (2011). La subtitulación al servicio del aprendizaje de lenguas: el entorno LvS. Babel. Revue internationale de la traduction / International fournal of Translation, 57(3), 305-323. https://dx.doi.org/10.1075/ babel.57.3.04rom

Sabaté-Carrove, M., \& Baiget, E. (2019). E-Learning as a Cooperative Tandem Means to improve the Students' Subtitling Skills. Learning and Advanced Teaching Methods (pp. 299-312). M Visa.

Sánchez-Requena, A. (2018). Intralingual Dubbing as a Tool for Developing Speaking Skills. Special Issue of Translation and Translanguaging in Multilingual Contexts. Audiovisual Translation in Applied Linguistics: Educational Perspectives, 4(1), 102-128. https://doi .org/10.1075/ttmc.00006.san

Sherman, J. (2003). Using authentic video in the language classroom. Cambridge: Cambridge University Press.

Sokoli, S. (2006, May, 1-6). A tool for the creation of foreign language learning activities 
based on film subtitling. Copenhagen Conference MuTra: Audiovisual Translation Scenarios (pp. 66-73). Retrieved from https://www.euroconferences.info/proceedings/ 2006_Proceedings/2006_Sokoli_Stravoula.pdf

Sokoli, S. (2015). ClipFlair: Foreign Language Learning through Interactive Revoicing and Captioning of Clips. Subtitles and Language Learning, 127-148.

Sokoli, S. (2018). Exploring the possibilities of interactive audiovisual activities for language learning. Translation and Translanguaging in Multilingual Contexts, 4, 77-100. https:// dx.doi.org/10.1075/ttmc.00005.sok

Talavan, N. (2007). Learning Vocabulary Through Authentic Video and Subtitles. Tesol-Spain. Newsletter, 31, 5-8.

Talaván, N. (2010). Subtitling as a Task and Subtitles as Support: Pedagogical Applications. In J. Díaz-Cintas, A. Matamala, \& J. Neves (Eds.), New insights into audiovisual translation and media accessibility: media for All 2 (pp. 285-299).

Talaván, N. (2013). La subtitulación en el aprendizaje de lenguas extranjeras. Barcelona: Octaedro.

Talaván, N., \& Ávila Cabrera, J. J. (2015). First insights into the combination of dubbing and subtitling as L2 didactic tools. In Y. Gambier, A. Caimi, \& C. Mariotti (Eds.), Subtitles and Language Learning (pp. 149-172). Peter Lang.

Talaván, N., \& Lertola, J. (2016). Active audiodescription to promote speaking skills in online environments. Sintagma. Revista de Lingüística, 28, 59-74. https://doi.org/10.21001/ sintagma.2016.28.04

Talaván, N., Lertola, J., \& Costal, T. (2016). iCap: Intralingual Captioning for Writing and Vocabulary Enhancement. Alicante Journal of English Studies, 29, 229-247. https:// doi.org/10.14198/raei.2016.29.13

Talaván, N., \& Rodríguez-Arancón, P. (2014). The use of reverse subtitling as an online collaborative language learning tool. The Interpreter and Translator Trainer, 8(1), 84101. https://dx.doi.org/10.1080/1750399x.2014.908559

Talaván, N., \& Rodríguez-Arancón, P. (2018). Voice-over to improve oral production skills. In J. D. Sanderson \& C. Botella-Tejera (Eds.), Focusing on Audiovisual Translation Research (pp. 211-236).

Thaler, E. (2014). Teaching English with films. Berlin: Ferdinand Schöningh.

Vanderplank, R. (1988). The value of teletext sub-titles in language learning. ELT fournal, 42(4), 272-281.

Vanderplank, R. (2010). Déjà vu? A decade of research on language laboratories, television and video in language learning. Language Teaching, 43(1), 1-37. https://doi.org/10 .1017/S0261444809990267

Vanderplank, R. (2016). "Effects of" and "effects with" captions: How exactly does watching a TV programme with same-language subtitles make a difference to language learners? Language Teaching, 49(2), 235-250. https://doi.org/10.1017/S0261444813000207

Wagener, D. (2006). Promoting independent learning skills using video on digital language laboratories. Computer Assisted Language Learning, 19(4-5), 279-286. https://doi.org/ 10.1080/09588220601043180

Wang, Y. C. (2012). Learning L2 vocabulary with American TV drama from the learner's perspective. English Language Teaching, 217-225. https://dx.doi.org/10.5539/ elt.v5n8p217

Weir, C. J. (2014). A Research Report on the Development of the Test of English for Academic Purposes (TEAP) Writing Test for Japanese University Entrants. Retrieved from https:// www.eiken.or.jp/teap/group/pdf/teap_writing_report.pdf

Williams, H., \& Thorne, D. (2000). The value of teletext subtitling as a medium for language learning. System, 28(2), 217-228. https://dx.doi.org/10.1016/s0346-251x(00)00008-7 